\title{
Temporal changes in grazing intensity and herbage quality within a Swiss fen meadow
}

\section{Journal Article}

Author(s):

Güsewell, Sabine; Pohl, Mandy; Gander, Antoine; Strehler, Catherine

Publication date:

2007-06

Permanent link:

https://doi.org/10.3929/ethz-b-000066889

Rights / license:

In Copyright - Non-Commercial Use Permitted

Originally published in:

Botanica Helvetica 117(1), https://doi.org/10.1007/s00035-007-0798-7 


\title{
Temporal changes in grazing intensity and herbage quality within a Swiss fen meadow
}

\author{
Sabine Güsewell ${ }^{1 *}$, Mandy Pohl ${ }^{1,2}$, Antoine Gander ${ }^{2}$, Catherine Strehler ${ }^{2}$ \\ ${ }^{1}$ Institute of Integrative Biology, ETH Zürich, Universitätsstrasse 16, CH-8092 Zürich; \\ e-mail: sabine.guesewell@env.ethz.ch \\ ${ }^{2}$ Groupe d'Etude et de Gestion, Grande Cariçaie, Champ-Pittet, CH-1400 Yverdon
}

Manuscript accepted 29 March 2007

\begin{abstract}
Güsewell S., Pohl M., Gander A. and Strehler C. 2007. Temporal changes in grazing intensity and herbage quality within a Swiss fen meadow. Bot. Helv. 117: 57-73.

Grazing is a possible tool for conservation management in wetlands, but a frequent problem is spatial variation in grazing intensity, which may promote the degradation of the vegetation. Temporal changes in grazing patterns may reduce this problem by leading to a more homogeneous overall use of the area. In a lakeshore wetland (2.8 ha) grazed by Scottish Highland cattle from May till September, we studied how the grazing of nine vegetation types changes seasonally and between years, and how this is related to the quantity and quality of the herbage. We observed cattle activity weekly throughout two grazing periods, determined the biomass and nutrient concentrations of the vegetation, analysed dung samples, and carried out clipping experiments to assess shoot regeneration after grazing. The annual grazing intensity varied seven-fold among vegetation types, and this pattern was closely similar in both years. In several vegetation types, however, grazing intensity changed seasonally. Cattle first grazed tall grassdominated vegetation (Phragmition, Phalaridion), which had the most digestible and nutrient-rich herbage, but the poor regeneration of dominant species forced the cattle to then graze small-sedge dominated, nutrient-poor fen vegetation (Caricion davallianae). These temporal changes in grazing patterns slightly reduced the spatial variation in grazing intensity. To take advantage of this effect, relatively long grazing seasons are preferable to shorter ones. Four years of grazing reduced the above-ground biomass production and nutrient concentrations of several vegetation types. Therefore, years without grazing may be needed to prevent a degradation of palatable plant communities with low grazing tolerance.
\end{abstract}

* Editor: Pascal Vittoz 
Key words: Calcareous fens, forage quality, N:P ratio, pasture utilisation, Scottish Highland cattle, wetland vegetation.

\section{Introduction}

Grazing by extensive cattle breeds is increasingly used in Central Europe to manage wet grasslands for nature conservation (Gordon et al. 1990; Stammel et al. 2003; Middleton and van Diggelen 2006). Grazing is often more effective than mowing in controlling the dominance of tall herbs or shrubs (Rozé 1993; Andersen and Calov 1996), but it may also promote some undesirable species (Vinther 1983; Bokdam and Gleichman 2000) and/or cause transfers of nutrients and propagules within the pasture (Augustine 2003; Edwards et al.2004; Mouissie et al.2005). This may lead to pronounced changes in the composition and productivity of the vegetation (van den Bos and Bakker 1990; Bokdam and Gleichman 2000). It is therefore not a-priori clear whether cattle grazing will indeed contribute to maintaining a diverse herbaceous vegetation in a particular wetland (Middleton and van Diggelen 2006).

An important determinant of how grazing affects the vegetation is the spatial pattern of pasture use. Free-ranging cattle tend to graze some parts of the pasture more intensively than others due to variation in the quantity or quality of available herbage (Bokdam and de Vries 1992; Matejková et al.2003; Lamoot et al. 2005). This is particularly likely to occur in wetlands that include several plant communities with contrasting productivity and nutritional quality (WallisDeVries and Schippers 1994). The concentration of grazing on nutritious vegetation patches can lead to local overgrazing and to insufficient management in the remaining pasture area (Jewell et al. 2005). Furthermore, if different parts of the pasture are used for grazing and resting, an excessive concentration of nutrients in resting areas may promote nutrient leaching and water pollution (Boddey et al. 2004; McGechan and Topp 2004). For all these reasons, spatial heterogeneity in pasture use limits the use of grazing as a tool for conservation management (Middleton and van Diggelen 2006).

Patterns of pasture use may vary in time, both seasonally and between years (Gander et al. 2003; Matejková et al. 2003; Ausden et al. 2005). Many wetlands are dominated by species with deciduous shoots that grow in spring and senesce in autumn, so that the nutrient and energy content of plant biomass decreases from spring to autumn and is low in winter (Bokdam and de Vries 1992; van Oene et al. 1999; Güsewell 2003). The water level also varies seasonally and from year to year, which may affect grazing behaviour. Such variations can potentially lead to a more homogeneous utilisation of a pasture provided that the intensively used areas actually change over time. For example, Bokdam (2001) proposed a model of cyclic succession for heathlands, where shifting grazing patterns maintained a shifting mosaic of vegetation patches. However, this mechanism only worked if animals chose to rest in the nutrientpoor vegetation patches and if initial soil fertility was intermediate (Bokdam and Gleichman 2000). These restrictions indicate that local site conditions may determine whether or not temporal variation in pasture use can contribute to the maintenance of a diverse vegetation.

An important wetland type in Central Europe is the fen meadow, with seasonal fluctuations in water level (Hájek et al. 2006) and a pronounced seasonal pattern of plant growth and senescence (Warnke-Grüttner 1990). In Switzerland, fen meadows generally occur on base-rich and rather impermeable soils, and periods of flooding are 
highly variable according to precipitation and snowmelt (Buttler and Gallandat 1990). Many Swiss fen meadows are very small, either naturally or due to agricultural use. They have traditionally been mown in autumn or winter and often comprise a smallscale mosaic of sedge-, grass- or forb-dominated plant communities (Güsewell and Edwards 1999; Bollens et al. 2001). Because of the small size and ecological properties of Swiss fen meadows, the behaviour of grazing cattle and their impact on the vegetation may differ from those described in other European wetland types (cf. references above). In particular, temporal variation in pasture use might be important because of the variable hydrology and seasonal vegetation development.

The aim of this study was to test whether grazing patterns of cattle within a fen meadow changed seasonally and between two years with contrasting precipitation regime. We further investigated whether seasonal variation in pasture use was driven by a seasonal depletion of herbage quantity or quality in the most nutritious vegetation types, e.g. due to a lack of regeneration after grazing. Based on our results, we discuss the potential importance of temporal variation in pasture use for cattle nutrition and grazing effects on the vegetation, and we derive some recommendations for grazing management in fen meadows with a mosaic of herbaceous plant communities.

\section{Methods}

\section{Study area}

The study site $\left(45^{\circ} 54^{\prime} \mathrm{N}, 6^{\circ} 56^{\prime} \mathrm{E}, 430 \mathrm{~m}\right.$ a.s.l.) is an 8 -ha fen area belonging to the Grande Cariçaie, a large wetland on the southeast shore of Lake Neuchâtel in western Switzerland (Buttler et al. 1985). The climate is suboceanic with a mean annual precipitation of $900 \mathrm{~mm} / \mathrm{yr}$, and a mean annual temperature of $10.4{ }^{\circ} \mathrm{C}$. In 2002 , the spring was wet, followed by an extremely hot and dry June; the rest of the summer was average in temperature and precipitation. In 2003, the weather was dry and extremely hot throughout the grazing season (Schär et al. 2004).

The site is a fen meadow, which is usually flooded in winter and spring but relatively dry in summer. The vegetation consists of a mosaic of wetland plant communities, bordered by alluvial forests on the upland side and reed stands on the lake side. Soils are base-rich ( $\mathrm{pH} 7$ ) gleysoils over sandy or clayey lake sediments. Topsoil thickness ranges from 5 to $20 \mathrm{~cm}$; organic matter ranges from $20 \%$ in drier places (Anmoor) to over $90 \%$ in permanently wet places. The soil $\mathrm{C} / \mathrm{N}$ ratio ranges from 12.7 to 16.1 (M. Pohl, unpublished data).

Until 1999, the site was mown in winter every third year (Güsewell and Le Nédic $2004)$; since 2000 , the central part of the site ( 2.8 ha) has been grazed by three young highland cattle (total grazing pressure $=0.5-0.7$ livestock units ha ${ }^{-1}$ ) from end May till mid September in an attempt to maintain its diverse vegetation (Gander et al. 2003). The grazing area was surrounded by an electric fence, and the cattle were supplied with a tank of water and a mineral lick (Provimi 8744, Rotterdam, The Netherlands), placed near the forest border. The mineral lick contained $5 \% \mathrm{P}, 10 \% \mathrm{Ca}, 10 \% \mathrm{Mg}$ and $8 \% \mathrm{Na}$. Per grazing season, two blocks of $20 \mathrm{~kg}$ each were supplied to the cattle, and approximately $30 \mathrm{~kg}$ per season were consumed.

The vegetation of the site was mapped in 2000 using a floristic key established previously for the entire Grande Cariçaie (C. Clerc, unpublished report). Nine vegetation types were distinguished, mostly at the level of phytosociological 
associations (Tab. 1); their names correspond to the dominant plant species $(\geq 25 \%$ cover). The full species composition of the vegetation types is given in Gander et al. (2003).

Most vegetation types occupy a single patch of vegetation within the grazing area (Fig. 1a). We could therefore not investigate independent, replicated patches of each vegetation type. When we present data by vegetation type in the following, we mean the particular vegetation patches occurring at the study site and not the vegetation types in general. To compare grazed and ungrazed vegetation, exclosures should have been built within each vegetation patch when setting up the experiment. However, so many exclosures in a small area might have modified cattle behaviour. Therefore, the fence surrounding the grazed area was drawn through four large, visually homogeneous vegetation patches, and differences appearing subsequently between the two sides of the fence were tentatively interpreted as effects of grazing (cf. arrows in Fig. 1a).

Tab. 1. Seasonal and interannual changes in the utilisation of the nine vegetation types, shown as the mean percentage of time spent grazing in each vegetation type on 4-5 days per period in 2002 and 2003 (total grazing time per day $=100 \%$ ). The percentage area of each vegetation type is given for comparison. Differences in grazing time between years and among seasons were tested with two-way ANOVA. $F$-ratios and significance levels are given $(* *, P<0.01$; * $P$ $<0.05)$.

\begin{tabular}{|c|c|c|c|c|c|c|c|c|c|c|c|}
\hline & & \multirow[t]{2}{*}{$\begin{array}{l}\text { Area } \\
(\%)\end{array}$} & \multicolumn{3}{|c|}{$\begin{array}{l}\text { Grazing } 2002 \\
\text { (\% of time) }\end{array}$} & \multicolumn{3}{|c|}{$\begin{array}{l}\text { Grazing } 2003 \\
\text { (\% of time) }\end{array}$} & \multicolumn{3}{|c|}{ ANOVA results $(F, p)$} \\
\hline & & & $\begin{array}{l}\text { May } \\
\text { June }\end{array}$ & July & $\begin{array}{l}\text { Aug } \\
\text { Sept }\end{array}$ & $\begin{array}{l}\text { May } \\
\text { June }\end{array}$ & July & $\begin{array}{l}\text { Aug } \\
\text { Sept }\end{array}$ & Year & Season & $\begin{array}{l}\text { Year* } \\
\text { season }\end{array}$ \\
\hline 1 & Dry Phalaridetum & 2.5 & 6.4 & 5.8 & 9.6 & 3.8 & 10.8 & 9.4 & 0.17 & 2.20 & 1.65 \\
\hline 2 & Wet Phalaridetum & 9.7 & 14.0 & 23.8 & 38.6 & 39.5 & 15.0 & 24.6 & 0.05 & 2.77 & $8.54 * *$ \\
\hline 3 & Caricetum acutiformis & 2.2 & 1.0 & 4.1 & 10.4 & 4.4 & 3.3 & 5.8 & 0.16 & $3.51 *$ & 1.76 \\
\hline 4 & Phragmitetum australis & 3.6 & 3.9 & 11.6 & 1.4 & 6.7 & 9.3 & 1.4 & $<0.01$ & 2.69 & 0.23 \\
\hline 5 & Schoenetum nigricantis & 3.5 & 3.3 & 5.8 & 4.4 & 2.7 & 6.2 & 10.1 & 0.81 & 1.54 & 0.92 \\
\hline 6 & Caricetum hostianae & 16.6 & 16.6 & 33.6 & 16.1 & 16.0 & 31.6 & 24.2 & 0.18 & $5.14 *$ & 0.52 \\
\hline 7 & Caricetum ripariae & 15.3 & 23.6 & 4.1 & 4.4 & 8.2 & 7.9 & 13.5 & 0.11 & $5.78 * *$ & $9.06 * *$ \\
\hline 8 & Cladietum marisci & 5.6 & 3.9 & 0.9 & 3.3 & 8.0 & 1.3 & 4.5 & 0.41 & 0.94 & 0.15 \\
\hline 9 & Caricetum elatae & 39.5 & 27.2 & 10.3 & 11.8 & 10.7 & 14.5 & 6.4 & 2.32 & 2.22 & 2.44 \\
\hline
\end{tabular}

\section{Cattle activity}

Cattle grazing activity was observed over two grazing seasons on one day per week ( 15 days in 2002 and 19 days in 2003). From dawn till dusk, we recorded the activity and position of each animal every minute during $30 \mathrm{~min}$ per hour. The animal was considered to be grazing if it grazed for at least $30 \mathrm{~s}$ during the minute of observation. To describe cattle position, the grazing area was subdivided into 94 cells of approximately $10 \mathrm{~m}$ by $30 \mathrm{~m}$ (Fig. 1b). Cell borders were marked in the field by planting coloured sticks every $10 \mathrm{~m}$ along the fence, which helped to visually determine the cell in which an animal was. To minimise our influence on cattle behaviour, we observed them from a stand $3 \mathrm{~m}$ in height built at the southeast corner of the pasture. If cattle moved towards the other side of the pasture, they were followed outside the fence.

Based on the number of grazing observations (minutes) made in each cell on each day, and the vegetation type(s) present in each cell (derived from the vegetation map), 
(a)

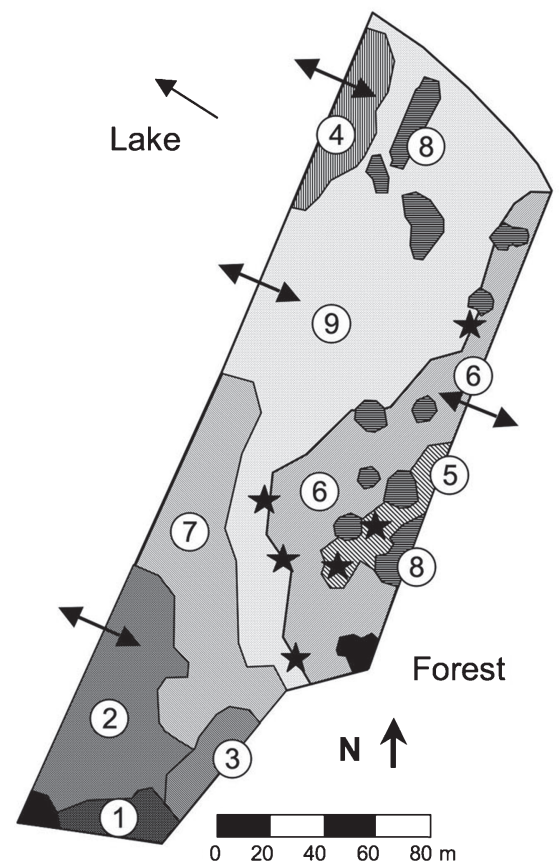

(b)

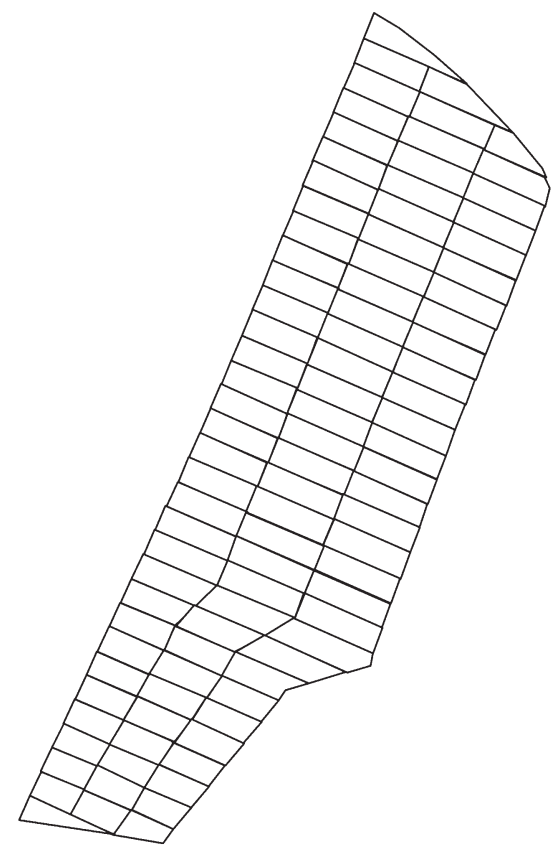

Fig. 1. Map of the grazing area ( $2.8 \mathrm{ha}$, surrounded by a fence). (a) Distribution of vegetation types (numbers as in Tab. 1), shrubs or trees (stars), the unvegetated resting areas (black), and the places where grazed and ungrazed vegetation were compared in 2003 (arrows); (b) cell grid used to record cattle position.

we calculated the percentage of grazing observations made in each vegetation type on each day. For cells including more than one vegetation type, cattle observations were allocated to vegetation types with an iterative algorithm. We first assumed that within a cell, vegetation types were grazed in proportion to their relative area in this cell. The sum of grazing observations allocated to each vegetation was then used to calculate an approximate grazing intensity for each vegetation type ( $\%$ of daily grazing observations divided by $\%$ of pasture area). In a second iteration, grazing observations per cell were distributed among vegetation types more accurately by considering vegetation types within a cell to be grazed in proportion to the product of their area and approximate grazing intensities. On this basis we calculated more precise grazing intensities. These were again used to distribute grazing observations within each cell among vegetation types. The grazing intensities obtained in the third iteration closely matched those obtained in the second iteration and were used to calculate the percentage of a day's grazing observations made in each vegetation type.

The distribution of cattle dung was mapped on 2 September 2002 and 23 September 2003 by walking along transects across the area and by counting the number of dung pats seen within $1 \mathrm{~m}$ on both sides of the line (using a stick to check the distance). The number of pats was noted every $5 \mathrm{~m}$ along the transect. Neighbouring transects were $10 \mathrm{~m}$ apart, so that $20 \%$ of the area were surveyed. Based on the vegetation map, every 
dung record was attributed to a vegetation type to estimate the percentage of dung deposited in each type. At five dates in 2002 and 2003, five fresh dung pats were collected, dried at $80{ }^{\circ} \mathrm{C}$ and ground in a rotatory mill. Total $\mathrm{N}$ and $\mathrm{P}$ concentrations were determined by digesting $150 \mathrm{mg}$ of ground material for $1 \mathrm{~h}$ at $420{ }^{\circ} \mathrm{C}$ with $98 \%$ $\mathrm{H}_{2} \mathrm{SO}_{4}$ and a copper sulphate-potassium sulphate additive (Merck Kjeltabs). Digests were analysed colorimetrically for $\mathrm{N}$ and $\mathrm{P}$ on the flow injection analyser (FIA Star, Foss Tecator, Höganäs, SE).

\section{Sampling of plant biomass and analysis of herbage quality}

Above-ground biomass and herbage quality were determined for each vegetation type in May, July and September 2002 (Fig. 1); the Schoenetum nigricantis, which occurrred as small patches within the Caricetum hostianae, was not sampled. In all other types we randomly sampled three plots per date by throwing a frame of $1 \mathrm{~m}^{2}$, clipping all vascular plants at ground level and removing the litter. The fresh mass of the entire sample was determined immediately; a sub-sample of $200 \mathrm{~g}$ was dried at $80{ }^{\circ} \mathrm{C}$ for three days and re-weighed to estimate the dry mass of the entire sample.

Above-ground biomass was sampled again in 2003 both within and outside the grazed area for the four vegetation types that occurred on both sides of the fence (wet Phalaridetum, Phragmitetum, Caricetum elatae and Caricetum hostianae; Fig. 1). To assess the ability of the vegetation to regenerate after grazing, we also installed three permanent plots $\left(1 \mathrm{~m}^{2}\right)$ within each vegetation type (grazed and ungrazed area) and harvested the biomass within these plots at each of the three sampling dates. The repeated clipping simulated intensive grazing.

Herbage quality was analysed in biomass sub-samples after grinding in a Retsch rotatory mill ( $1 \mathrm{~mm}$ mesh). In July 2003, only samples from the grazed area without repeated clipping were analysed. Total $\mathrm{N}$ and $\mathrm{P}$ concentrations were determined in $150 \mathrm{mg}$-subsamples as described above for dung samples.

Herbage digestibility was estimated in vitro for the 2003 biomass (grazed area) with the pepsin-cellulase method (Jones and Hayward 1975): $200 \mathrm{mg}$ of ground plant material were pre-treated with $20 \mathrm{ml} 0.2 \%$ pepsin $(0.7 \mathrm{FIP}-\mathrm{U} / \mathrm{mg}$, Merck) in $0.1 \mathrm{~N} \mathrm{HCl}$ for $24 \mathrm{~h}$ at $40^{\circ} \mathrm{C}$. After vacuum filtration (Filter LS 14, Schleicher and Schuell, Dassel, Germany), the residue was suspended in a cellulase solution (125 mg Trichoderma viride, BHD Ltd. Poole, Dorset, UK) in $20 \mathrm{ml}$ citrate buffer $\mathrm{pH} 4.6$ ); the mixture was incubated for $48 \mathrm{~h}$ at $40{ }^{\circ} \mathrm{C}$. The soluble digestion products were removed through vacuum filtration, and the residue was dried for $24 \mathrm{~h}$ at $70{ }^{\circ} \mathrm{C}$ and weighed to calculate the fraction of the material that had been digested.

\section{Statistical analysis}

To test for temporal changes in grazing intensity, observation dates were subdivided into three seasonal periods: May-June, July, August-September. For each vegetation type, differences in mean grazing intensity between seasonal periods and years were tested with two-way ANOVA using JMP version 5 (SAS Institute Inc., Cary, NC, USA). Because observations formed a time series, the absence of temporal autocorrelation in the residuals of the ANOVA models was checked using R version 2.3.0 (R Foundation for Statistical Computing, Vienna, Austria).

All biomass and herbage quality data except for digestibility were log-transformed to meet the assumptions of parametric tests. Differences in above-ground biomass and 
nutrient concentrations among sampling dates in 2002 were analysed for each vegetation type with one-way Anova. Differences in biomass and nutrient concentrations between the grazed and ungrazed areas in May 2003 were analysed for each vegetation type with t-Tests. The effects of grazing and clipping (four treatments) on biomass in July and September 2003 were analysed for each sampling date and vegetation type with one-way ANova followed by pairwise comparisons of treatment means with Tukey HSD tests; this test was used, rather than two-way ANova, because pairwise differences between particular treatments were relevant for the interpretation of results. The programme JMP (see above) was used for these tests.

\section{Results}

\section{Cattle activity}

The distribution of grazing among the nine vegetation types varied seasonally, and seasonal patterns also differed between years. In 2002, cattle mainly grazed the Caricetum elatae and $C$. ripariae in June, the $C$. hostianae in July, and the wet Phalaridetum in August. In 2003, they mainly grazed the wet Phalaridetum in MayJune, the $C$. hostianae in July, and both vegetation types in August (Tab. 1). Seasonal changes were significant for three vegetation types, and year-by-season interactions for two vegetation types (Tab. 1).

Despite some differences in seasonal patterns, the overall distribution of grazing among the nine vegetation types was similar in both years: percentage grazing time did not differ between years for any of the vegetation types (Tab. 1), so that grazing intensity in 2002 and 2003 strongly correlated with each other (Fig. 2a). In both years, the dry and wet Phalaridetum and the Caricetum acutiformis were grazed most intensively relative to their area, whereas the Caricetum ripariae, $C$. elatae and Cladietum marisci were grazed least intensively.
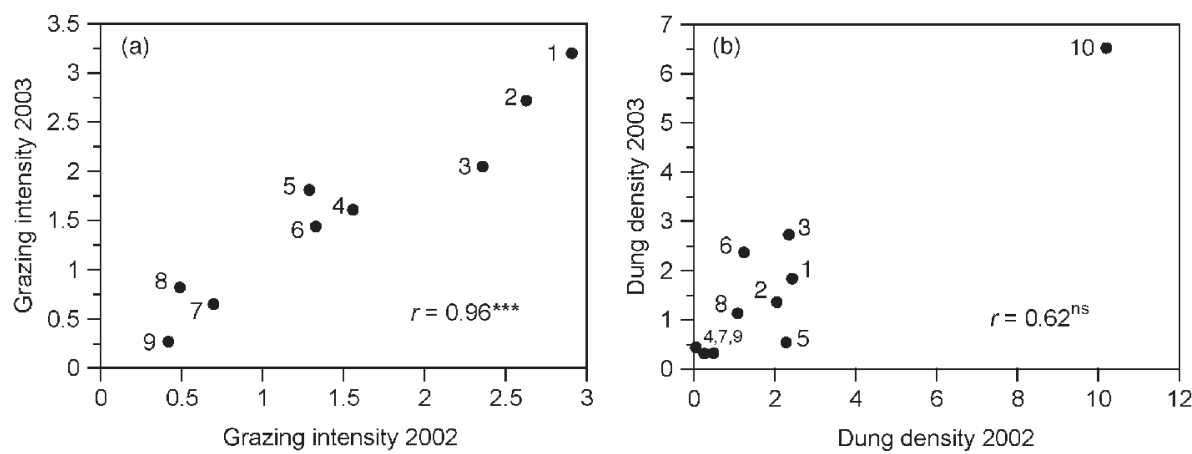

Fig. 2. Relationships between (a) grazing intensity and (b) dung density in 2002 and 2003. For each vegetation type, grazing intensity was calculated as percentage of grazing time (from all observation dates) divided by percentage area (cf. Tab. 1), and dung density as percentage of dung pats divided by percentage area. Numbers of vegetation types refer to Table $1 ; 10=$ unvegetated resting areas. Pearson correlation coefficients and their significance ${ }^{* * *}, P<$ 0.001) were calculated across the nine vegetation types (without unvegetated area). 
Dung distribution among vegetation types differed between the two years: dung pat density in 2002 and in 2003 did not correlate with each other across the nine vegetation types (Fig. 2b). In both years, however, a large part of the dung was dropped in the unvegetated resting areas (Fig. 2b). Concentrations of $\mathrm{N}$ and $\mathrm{P}$ in cattle dung decreased in the course of the grazing season (Fig. 3). The decrease in $\mathrm{N}$ concentration was moderate, but the $\mathrm{P}$ concentration in September was only $40 \%$ of that in May. Accordingly, the N:P ratio of the dung increased from 2.7-2.8 in May to 5.7-6.8 in September. Dung N and P concentrations were closely similar in 2002 and 2003, except for a lower P concentration in September 2003 (Fig. 3).

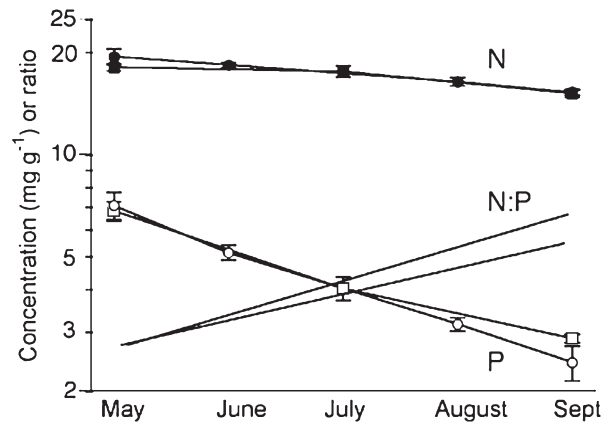

Fig. 3. Changes in $\mathrm{N}$ and $\mathrm{P}$ concentrations and $\mathrm{N}: \mathrm{P}$ ratios of cattle dung during the grazing seasons 2002 (squares) and 2003 (circles). Data are means $\pm S E$ of five fresh dung pats at each collection date.

\section{Herbage quantity and quality}

The above-ground biomass of the vegetation decreased between May and September 2002 in most vegetation types with grazing intensity $\geq 1$ but increased in vegetation types with grazing intensity $<1$ (Fig. 4). At the beginning of the fourth grazing season (May 2003), the above-ground biomass was generally lower within the grazed area than outside (Fig. 5a). Differences in shoot biomass between grazed and ungrazed area further increased in the course of the grazing season, except for the Caricetum elatae (Fig. 5b,c).

Shoot regeneration after experimental clipping was poor in the wet Phalaridetum and Phragmitetum: The above-ground biomass of clipped plots was very low both in July and in September 2003, and the total amount of shoot biomass produced in the ungrazed-clipped plots was much lower than that produced in the undisturbed plots (Fig. 5b,c). In the Caricetum hostianae and C. elatae, shoots regenerated better: the above-ground biomass in July did not differ significantly between ungrazed-clipped and undisturbed plots (Fig. 5b), and the total shoot biomass produced in ungrazed-clipped plots equalled or exceeded that produced in undisturbed plots (Fig. 5b,c). Shoot biomass in clipped plots (i.e. shoot regeneration after clipping) did not differ between grazed and ungrazed area in July (Fig. 5b). In September, shoot regeneration was greater in the grazed area for the wet Palaridetum, but in the ungrazed area for the $C$. elatae (Fig. 5c).

Nutrient concentrations in the above-ground biomass of the vegetation generally decreased in the course of the grazing season (Fig. 6; Tab. 2). In May 2003, nutrient 


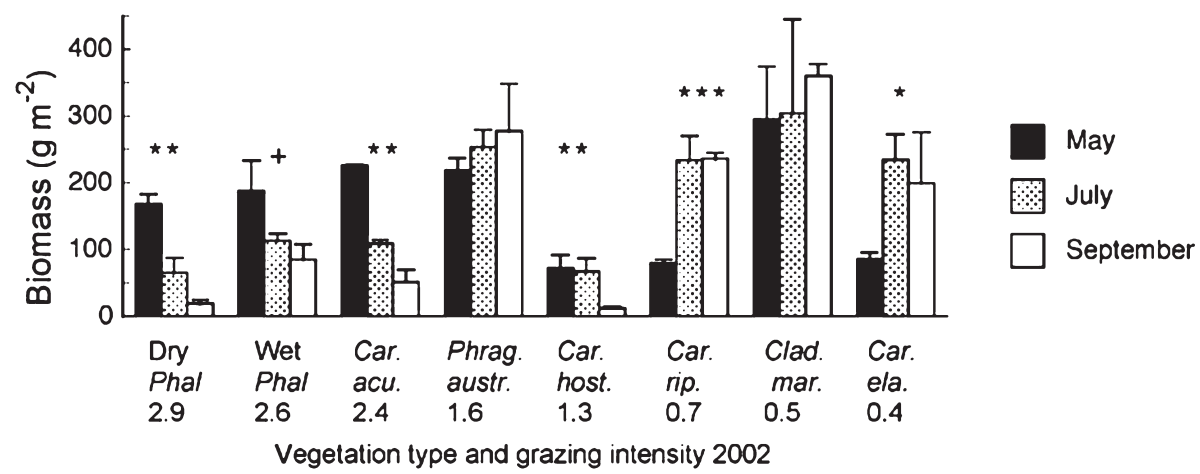

Fig. 4. Seasonal changes in the above-ground biomass of the vegetation (dry mass, means and $\mathrm{SE}, \mathrm{n}=3$ ). For each vegetation type, the significance of differences between the three sampling dates was tested with one-way ANOVA (***, $P<0.001$; **, $P<0.01$; *, $P<0.05 ;+, P<0.10$ ). Vegetation types are ordered by decreasing grazing intensity in 2002.

concentrations were generally greater in the grazed area than in the ungrazed area for the wet Phalaridetum, while this was opposite for the other vegetation types (Tab. 2). Nutrient concentrations in September 2003 were increased by experimental clipping in all vegetation types, whereas they were increased by grazing only in the wet Phalaridetum (Fig. 7).

Tab. 2. Nitrogen and phosphorus concentrations and digestibility (mean $\pm S E, n=3$ ) of the above-ground biomass of four vegetation types, harvested outside the fenced grazing area in May ("ungrazed"), as well as within the grazed area in May, July and September 2003 (plots not clipped previously, cf. Fig. 2). Significant differences between grazed and ungrazed area in May are indicated by asterisks ( $t$-Test, $P<0.05$ ); significant pairwise differences between sampling dates in the grazed area are given by superscripts; means without common letter differ significantly (Tukey test, $P<0.05$ ).

\begin{tabular}{|c|c|c|c|c|}
\hline & \multirow{2}{*}{$\begin{array}{l}\text { Ungrazed } \\
\text { May }\end{array}$} & \multicolumn{3}{|c|}{ Grazed } \\
\hline & & May & July & September \\
\hline \multicolumn{5}{|c|}{$\mathrm{N}$ concentration $\left(\mathrm{mg} \mathrm{g}^{-1}\right)$} \\
\hline Wet Phalaridetum & $19.9 \pm 0.5^{*}$ & $22.7 \pm 0.4^{\mathrm{a}}$ & $13.0 \pm 1.1^{\mathrm{b}}$ & $16.1 \pm 2.2^{\mathrm{ab}}$ \\
\hline Phragmitetum & $26.0 \pm 1.3^{*}$ & $20.1 \pm 1.0^{\mathrm{a}}$ & $8.6 \pm 0.6^{\mathrm{b}}$ & $6.8 \pm 0.9^{\mathrm{b}}$ \\
\hline Caricetum hostianae & $18.2 \pm 1.2 *$ & $14.4 \pm 0.7^{\mathrm{a}}$ & $11.6 \pm 0.5^{\mathrm{a}}$ & $12.1 \pm 1.7^{\mathrm{a}}$ \\
\hline Caricetum elatae & $16.7 \pm 1.1$ & $15.1 \pm 1.0^{\mathrm{a}}$ & $10.8 \pm 0.2^{\mathrm{b}}$ & $9.5 \pm 0.7^{\mathrm{b}}$ \\
\hline \multicolumn{5}{|c|}{$\mathrm{P}$ concentration $\left(\mathrm{mg} \mathrm{g}^{-1}\right)$} \\
\hline Wet Phalaridetum & $2.4 \pm 0.4$ & $3.2 \pm 0.1^{\mathrm{a}}$ & $1.8 \pm 0.1^{\mathrm{b}}$ & $2.9 \pm 0.5^{\mathrm{ab}}$ \\
\hline Phragmitetum & $3.6 \pm 0.1 *$ & $2.6 \pm 0.2^{\mathrm{a}}$ & $0.8 \pm 0.1^{\mathrm{b}}$ & $0.6 \pm 0.1^{\mathrm{b}}$ \\
\hline Caricetum hostianae & $1.3 \pm 0.3^{*}$ & $0.8 \pm 0.1^{\mathrm{a}}$ & $0.5 \pm 0.0^{\mathrm{b}}$ & $0.4 \pm 0.1^{\mathrm{b}}$ \\
\hline Caricetum elatae & $1.8 \pm 0.1^{*}$ & $1.3 \pm 0.1^{\mathrm{a}}$ & $1.0 \pm 0.2^{\mathrm{a}}$ & $0.3 \pm 0.1^{\mathrm{b}}$ \\
\hline \multicolumn{5}{|l|}{ Digestibility (\%) } \\
\hline Wet Phalaridetum & not & $50.5 \pm 3.4^{\mathrm{a}}$ & $23.2 \pm 7.3^{\mathrm{b}}$ & $39.2 \pm 3.3^{\mathrm{ab}}$ \\
\hline Phragmitetum & determined & $42.3 \pm 3.0^{\mathrm{a}}$ & $25.1 \pm 1.2^{\mathrm{b}}$ & $21.4 \pm 2.1^{\mathrm{b}}$ \\
\hline Caricetum hostianae & & $47.1 \pm 2.4^{\mathrm{a}}$ & $34.6 \pm 0.3^{\mathrm{b}}$ & $35.0 \pm 3.9^{\mathrm{b}}$ \\
\hline Caricetum elatae & & $38.3 \pm 1.5^{\mathrm{a}}$ & $34.9 \pm 2.3^{\mathrm{a}}$ & $25.7 \pm 0.9^{\mathrm{b}}$ \\
\hline
\end{tabular}



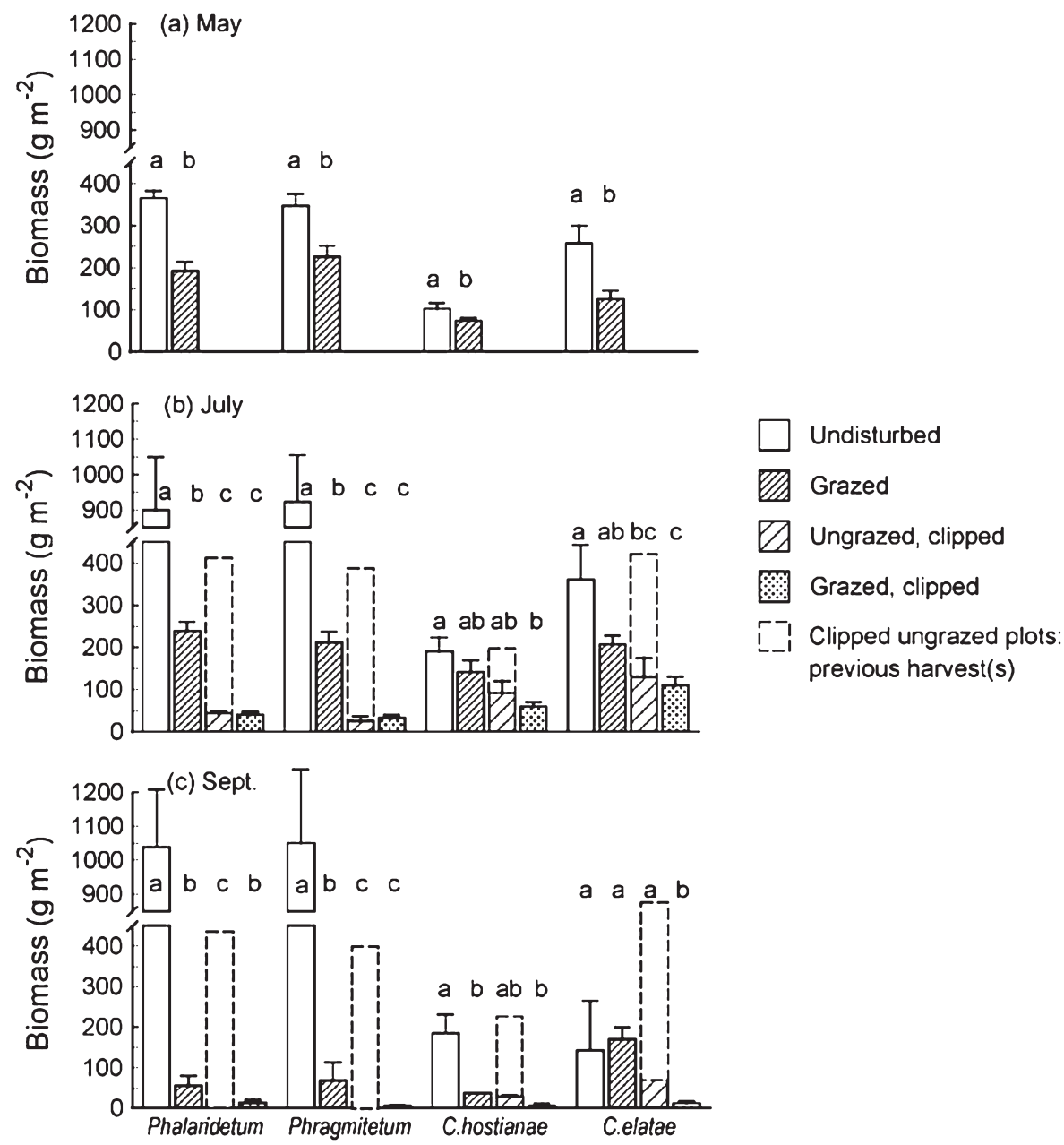

Fig. 5. Effects of grazing and clipping on the above-ground biomass (dry mass, means and $S E$ ) of four wetland vegetation types in (a) May, (b) July and (c) September 2003. In May, 4-6 plots were harvested in each vegetation type both within the grazed area and in the ungrazed area outside the fence. In July and September, $2-3$ of the plots were harvested again to assess regrowth after clipping ('clipped');2-3 additional plots were harvested at random ('ungrazed' or 'grazed'). Differences among treatments were tested with Tukey tests; in each month and vegetation type, means that do not share the same letter differ significantly $(P<0.05)$. For the ungrazed, clipped plots, additional bars in (b) and (c) visualise the amount of biomass removed at the previous harvests, so that the total length of the dashed bar represents total above-ground production (not included in the statistical analysis).

The estimated digestibility of the herbage was generally low and decreased from May to September 2003 in all vegetation types (Tab. 2). Values close to $50 \%$ were only found in May in the Phalaridetum and Caricetum hostianae. 


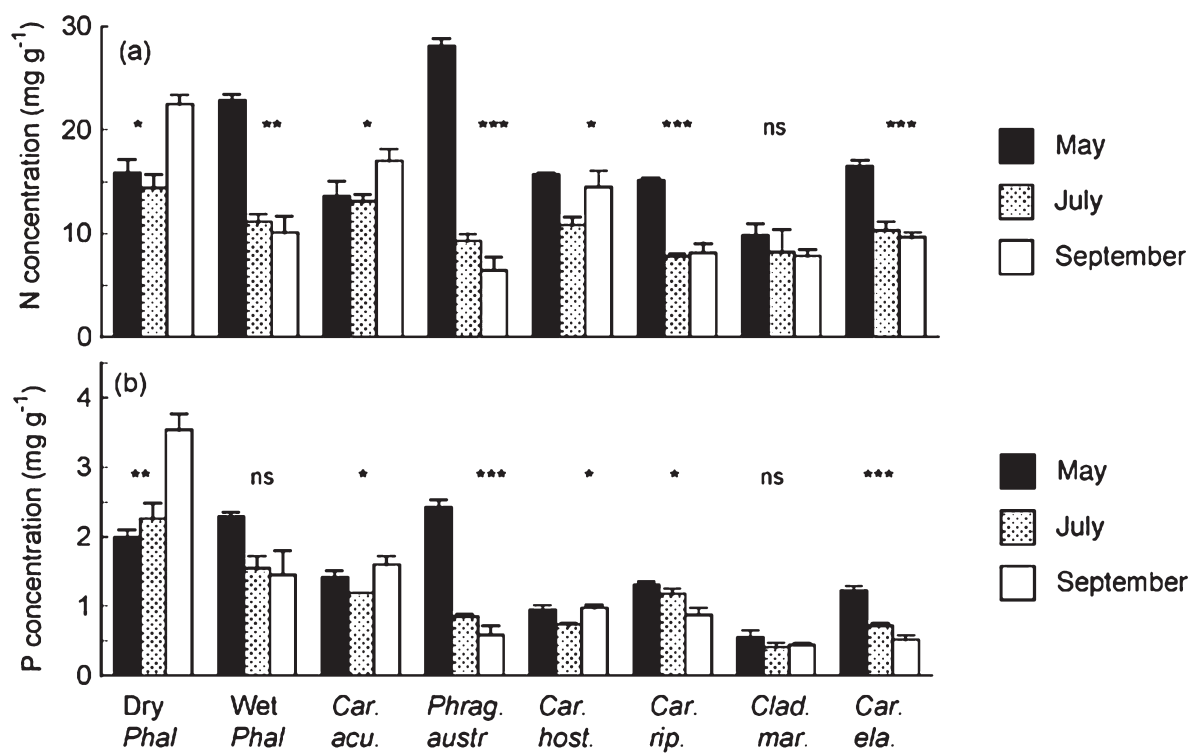

Fig. 6. Seasonal changes in (a) N and (b) P concentrations (means and $S E$ ) in the above-ground biomass of nine vegetation types during 2002. For each vegetation type, the significance of differences between the three sampling dates was tested with one-way ANOVA (***, $P<0.001$; **, $P<0.01 ; *, P<0.05 ;+, P<0.10)$.

\section{Discussion}

Importance of temporal variation in grazing patterns

Grazing intensity differed considerably among vegetation types. As hypothesised, this spatial pattern varied seasonally, and for some of the vegetation types, the seasonal pattern differed between two years with contrasting precipitation regime. Nevertheless, overall pasture use was remarkably similar in both years, suggesting that this was determined by food availability more than by water level (Humphrey and Patterson 2000). Herbage quantity obviously limited the use of the vegetation types with highest nutritional quality (Phalaridion): the poor shoot regeneration of the dominant species after grazing, as revealed by the clipping experiments, forced cattle to use other vegetation types, such as the Caricetum hostianae and $C$. acutiformis. In the Phragmition, a rather high amount of biomass apparently remained in late summer (Fig. 4, 5c) because cattle had mainly browsed the upper part of the shoots, but the remaining culms were unpalatable due to their extremely low digestibility and nitrogen content (Tab. 2). Low herbage quality also generally caused a low grazing intensity in most vegetation types dominated by tall sedges (C. elatae, $C$. ripariae, Cladietum marisci), even though herbage availability was highest there in late summer. The only exception was spring 2002, when the $C$. elatae and $C$. ripariae were grazed more intensively (Gander et al. 2003). However, we observed that during this time, cattle mainly consumed young shoots of $P$. australis, and not the dominant sedge species (Gander et al. 2003). 
(a) Nitrogen

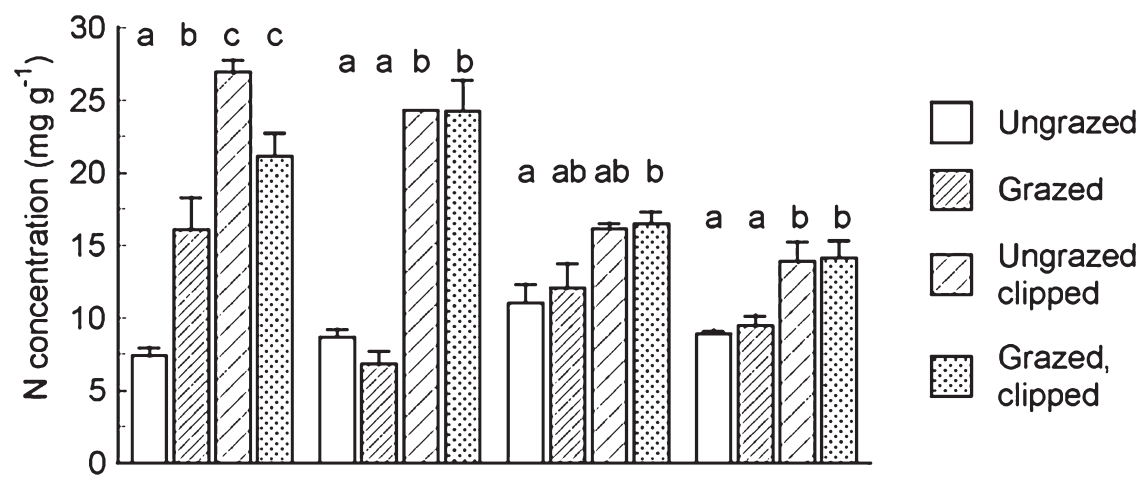

(b) Phosphorus

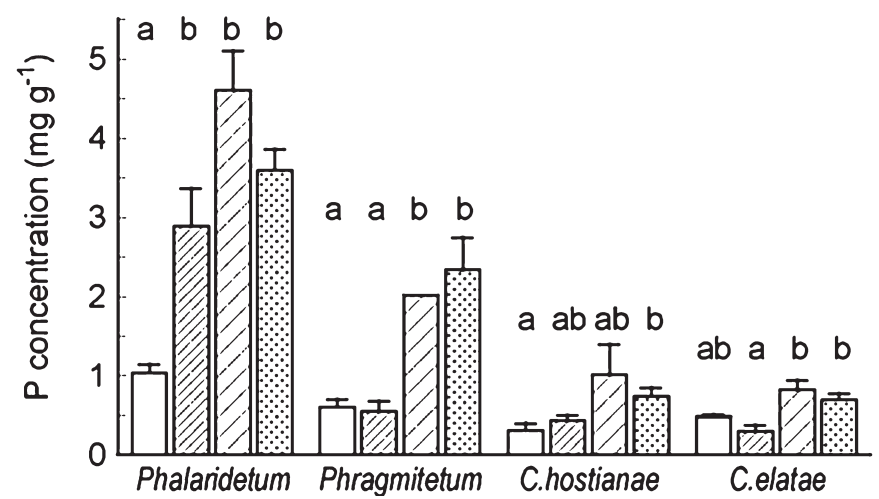

Fig. 7. Effects of grazing and experimental clipping on (a) $\mathrm{N}$ and (b) $\mathrm{P}$ concentrations (means and $S E$ ) in the above-ground biomass of four vegetation types in September 2003. Differences among the four treatments were tested with Tukey tests; in each vegetation type, means that do not share the same letter differ significantly $(P<0.05)$.

Temporal changes in grazing patterns contributed to some extent to a more homogeneous use of the pasture: The $C$. hostianae and $C$. acutiformis were mostly grazed in the second and third part of the summer, respectively, and would have been grazed much less intensively if the grazing season has been shorter or if the area covered by the preferred vegetation types had been larger. Yet, temporal changes in pasture use were insufficient to prevent a strong difference in grazing intensity between the nutritious Phalaridetum and Phragmition vegetation and the most unpalatable tallsedge communities ( $C$. elatae, $C$. ripariae, Cladietum marisci). The main aims of conservation management were still reached: all small shrubs and tree sapling had been killed after three years of grazing, and the tall grass Phragmites australis was strongly reduced in all sedge-dominated plant communities. However, the unequal distribution of grazing did have nutritional implications for vegetation and cattle, as discussed in the following. 


\section{Implications of grazing patterns for nutrient re-distribution by cattle}

A concern with grazing in wetlands of high conservation value is that this type of management might increase biomass production by increasing nutrient availability, or that nutrients might be re-distributed from nutrient-rich to nutrient-poor areas (Bokdam and Gleichman 2000; Bokdam 2001; Mouissie et al. 2005). Both effects could contribute to the loss of species from low-productive, mesotrophic wetland plant communities. No evidence for such effects was observed at our study site: after three grazing seasons, above-ground biomass production was lower within the grazed area than outside, and nutrient concentrations in plant biomass also tended to be lower in the grazed area, except for the nutrient-rich wet Phalaridetum (Tab. 2). This suggests that cattle actually strengthened the pre-existing differences in nutrient availability (Wilson and Agnew 1992).

Nutrient re-distribution from nutrient-rich to nutrient-poor areas may arise if cattle tend to rest in the nutrient-poor areas while grazing the more nutrient-rich ones (Bokdam and Gleichman 2000). The reverse occurred here: Because palatable food was rapidly depleted in the most nutrient-rich areas, cattle were forced to graze also the nutrient-poor, species-rich Caricetum hostianae. In contrast, the preferred resting places remained the same throughout the grazing season; these included the most nutrient-rich vegetation types as well as the adjacent unvegetated, sheltered spots (Gander et al. 2003). Although patterns of dung deposition somewhat changed between the two years (Fig. 2b), this did not alter the fact that most of the dung was deposited in the nutrient-rich areas. In addition, the nutrient content of the dung strongly decreased in the course of the season, when the cattle increasingly grazed the nutrient-poor areas. As a result, dung dropped while cattle were grazing would on average cause smaller nutrient inputs to mesotrophic vegetation than to eutrophic vegetation.

Our observations therefore suggest that through their behaviour, cattle moved nutrients from nutrient-poor to nutrient-rich areas. Such a concentration of nutrients is commonly observed when topographic features, water sources or sheltering structures create fixed resting areas (Haynes and Williams 1999; Boddey et al. 2004; Edwards et al. 2004). In wetlands, the effect might possibly be negated by a redistribution of nutrients when the site is flooded (McGechan 2003; McGechan and Topp 2004), but to our knowledge the importance of this process has not yet been investigated in fen meadows.

\section{Cattle nutrition}

A frequent problem for grazing animals in wetlands is nutritional deficiency (Bokdam and de Vries 1992; Menard et al. 2002). Herbage quality was poor in most vegetation types of our study site, especially in the second part of the grazing season. The estimated maintenance requirements of extensive beef cattle breeds ( $\mathrm{N}$ concentration of $12 \mathrm{mg} / \mathrm{g}$ dry matter, P concentration of $2.2 \mathrm{mg} / \mathrm{g}$ dry matter, digestibility of $50 \%$; Bokdam and de Vries 1992), were only met by the wet and dry Phalaridetum, by the Phragmitetum at the beginning of the grazing season, and nearly by the $C$. acutiformis (Fig. 6). These vegetation types were indeed grazed most intensively. This selectivity contrasts with the observations of WallisDeVries and Schippers (1994) in a Dutch riparian wetland, where vegetation types were not used selectively despite variation in herbage quality. All riparian vegetation types compared by WallisDeVries 
and Schippers (1994) had P concentrations above $2 \mathrm{mg} / \mathrm{g}$ and a higher digestibility than the vegetation types of our study site, which may explain why they were grazed rather indifferently.

In both years of our study, cattle first depleted their preferred herbage and then moved to vegetation with relatively high digestibility and $\mathrm{N}$ concentration but low $\mathrm{P}$ concentration. Selection for herbage with high digestibility (i.e. low fibre content) has also been revealed in wild ungulates (Forsyth et al. 2005) and is probably the main reason for the avoidance of vegetation dominated by tall sedges (this study, except for C. acutiformis) or rushes (Humphrey and Patterson 2000).

The shift towards herbage with inadequate $\mathrm{P}$ content was reflected by cattle dung, whose $\mathrm{P}$ concentration decreased dramatically in the course of the grazing season. Symptoms of P deficiency (e.g. osteoporosis) were found in wild ungulates feeding on herbage with P concentrations between 1 and $2 \mathrm{mg} / \mathrm{g}$ (Groot Bruinderink et al. 2000; Ohlson and Staaland 2001). Severe P deficiency, leading to behavioural changes such as carnivory, occurred in cattle kept year-round on heathland with an average $\mathrm{P}$ concentration of $1 \mathrm{mg} / \mathrm{g}$ (WallisDeVries 1996). At our study sites, most vegetation types had even lower P concentrations in the second part of the grazing season, suggesting even worse P deficiency. A more P-rich food supplement than the mineral lick used in this study would probably have alleviated the P deficiency, but it would also have increased $\mathrm{P}$ inputs to the vegetation. This might have caused an unwanted eutrophication to the mesotrophic plant communities, such as the $C$. hostianae.

\section{Implications for the use of grazing in the management of small wetlands}

The 2.8-ha area grazed here was much smaller than grazing areas studied elsewhere. We found that even in such a small area, cattle used vegetation types very selectively. Despite possible edge effects (fence, water supply), food selection reflected variation in herbage quantity and quality (see above); these in turn reflected variation in soil types and water level. Thus, results obtained in larger-scale studies remain essentially valid at a smaller scale. This is important because many wetlands nowadays are small and scattered within the agricultural landscape (Galatowitsch 2006); these wetlands particularly need appropriate conservation management as they are at high risk of deterioration through eutrophication (Brülisauer and Klötzli 1998).

Our observations have suggested that the grazing regime applied here $(0.5-0.7$ livestock units ha ${ }^{-1}$ for four months per year) led to nutrient (especially $\mathrm{P}$ ) deficiency for the cattle and a reduced productivity of the vegetation after a few years. It would therefore not be sustainable in this type of vegetation. A shorter grazing season would tend to strengthen the spatial concentration of grazing on the most nutritious vegetation types (e.g. Humphrey and Patterson 2000). This would only be advisable when the purpose is precisely to promote selective grazing, e.g. to control the encroachment of Phragmites australis within sedge-dominated vegetation. Observations in another Swiss fen showed that most shoots of $P$. australis had been browsed after ten days of grazing in early June (S. Güsewell, pers. obs.).

If the aim is to promote a spatially more homogeneous use of the pasture, relatively long grazing seasons appear preferable because of the seasonal shifts in pasture use. Cattle may need P-rich food supplements after the grazing season to restore their $\mathrm{P}$ balance. An alternation of years with and without grazing would probably maintain the productivity of the vegetation by allowing plants to replenish belowground reserves (Güsewell 2003). If wetlands contain a mosaic of contrasting vegetation types, a 
eutrophication of the nutrient-poor vegetation types can probably be avoided if the nutrient-rich vegetation types occupy only a small portion of the grazing area, and if the availability of shelter and water encourages cattle to rest in the nutrient-rich parts of the pasture.

\section{Résumé}

Le pacage peut servir à entretenir des marais dans un but de conservation, mais si la végétation d'un site est hétérogène, le broutage se concentre souvent dans un petite partie de la zone pâturée, et ce déséquilibre favorise la dégradation de la végétation. Cependant, si la distribution spatiale du broutage change au cours du temps, l'utilisation du pâturage sera plus équilibrée que si les mêmes parties sont toujours broutées intensivement. Nous avons étudié l'importance de ces changements dans une zone alluviale du lac de Neuchâtel comprenant neuf types de végétation différents. Dans une surface de 2.8 ha pâturée de mai à septembre par des bovins Highland, nous avons observé la distribution du broutage chaque semaine pendant deux saisons de pacage. Nous avons également analysé la quantité et la qualité de la biomasse végétale, et nous avons conduit un essai de coupe pour évaluer la capacité de régénération de la végétation qui a été broutée. La durée annuelle du broutage variait fortement entre les types de végétation, et il y avait peu de différence entre les deux années d'observation. En revanche, l'intensité de broutage changeait au cours de l'été pour plusieurs types de végétation. Les bovins broutaient d'abord la végétation dominée par de hautes herbes (Phragmition, Phalaridion) et riche en nutriments, mais la régénération faible des espèces dominantes après le broutage forçait les bovins à brouter ensuite la prairie de petites laiches (Caricion davallianae), pauve notemment en phosphore. Ce changement a légèrement réduit la variation spatiale de l'intensité du broutage. Pour en profiter, il faut prévoir des périodes annuelles de pacage relativement longues. Cependant, dans le site étudié ici, quatre années consécutives de pacage ont réduit la productivité et les teneurs en nutriments de certains types de végétation. Pour éviter la dégradation d'une végétation sensible au broutage, il semble préférable d'intercaler des années sans entretien, permettant aux espèces dominantes de se régénérer.

We thank Pierre-Alain Chevalet and Norbert Ponnaz for their great help during field work, Christian Clerc for the identification of plant species, Alexandre Ghiraldi and Christophe Le Nédic for computing support, François Bolle for setting up the observation system, Rose Trachsler and Marilyn Gaschen for excellent laboratory work, as well as François Fréléchoux, Michael Kreuzer, Pascal Vittoz and Martin Schütz for valuable comments on drafts of the manuscript.

\section{References}

Andersen U.V. and Calov B. 1996. Long-term effects of sheep grazing on giant hogweed (Heracleum mantegazzianum). Hydrobiol. 340: 277 - 284.

Augustine D.J. 2003. Long-term, livestock-mediated redistribution of nitrogen and phosphorus in an East African savanna. J. Appl. Ecol. 40: 137 - 149.

Ausden M., Hall M., Pearson P. and Strudwick T. 2005. The effects of cattle grazing on tall-herb fen vegetation and molluscs. Biol. Conserv. 122: 317 - 326.

Boddey R.M., Macedo R., Tarré R.M., Ferreira E., de Oliveira O.C., de P. Rezende C., Cantarutti R.B., Pereira J.M., Alves B.J.R. and Urquiaga S. 2004. Nitrogen cycling in 
Brachiaria pastures: the key to understanding the process of pasture decline. Agric. Ecosyst. Environ. 103: 389 - 403.

Bokdam J. 2001. Effects of browsing and grazing on cyclic succession in nutrient-limited ecosystems. J. Veg. Sci. 12: 875 - 886.

Bokdam J. and de Vries M.F.W. 1992. Forage quality as a limiting factor for cattle grazing in isolated Dutch nature reserves. Conserv. Biol. 6:399 - 408.

Bokdam J. and Gleichman J.M. 2000. Effects of grazing by free-ranging cattle on vegetation dynamics in a continental north-west European heathland. J. Appl. Ecol. 37: 415 - 431

Bollens U., Güsewell S. and Klötzli F. 2001. Vegetation changes in two Swiss fens affected by eutrophication and desiccation. Bot. Helv. 111: 139 - 155.

Brülisauer A. and Klötzli F. 1998. Habitat factors related to the invasion of reeds (Phragmites australis) into wet meadows of the Swiss Midlands. Z. Ökol. Natursch. 7: 125 - 136.

Buttler A., Buche M., Cornali P. und Gobat J.-M. 1985. Historischer und ökologischer Überblick über das Südostufer des Neuenburger Sees. Telma 15: $31-42$.

Buttler A. et Gallandat J.-D. 1990. Phytosociologie des prairies humides de la Rive Sud du lac de Neuchâtel (Suisse) et modèle de succession autogène. Phytocoenologia 18: 129 - 158.

Edwards P.J., Berry N.R., Güsewell S., Jewell P.L. and Kreuzer M. 2004. Long-term effects of cattle grazing upon the nutrient status of alpine pastures. In: Lüscher A., Jeangros B., Kessler W., Huguenin O., Lobsiger M., Millar N. and Suter D. (eds.): Land Use Systems in Grassland Dominated Regions. Vdf Hochschulverlag, Zürich, 302 - 304.

Forsyth D.M., Richardson S.J. and Menchenton K. 2005. Foliar fibre predicts diet selection by invasive Red Deer Cervus elaphus scoticus in a temperate New Zealand forest. Funct. Ecol. 19: 495 - 504.

Galatowitsch S. 2006. Restoring prairie pothole wetlands: does the species pool concept offer decision-making guidance for re-vegetation? Appl. Veg. Sci. 9: $261-270$.

Gander A., Rockmann A., Strehler C. and Güsewell S. 2003. Habitat use by Scottish Highland cattle in a lakeshore wetland. Bull. Geobot. Inst. ETH 69: 3 - 16.

Gordon I.J., Duncan P., Grillas P. and Lecomte T. 1990. The use of domestic herbivores in the conservation of the biological richness of European wetlands. Bull. Ecol. 21: 49 - 60 .

Groot Bruinderink G.W.T.A., Lammertsma D.R. and Hazebroek E. 2000. Effects of cessation of supplemental feeding on mineral status of red deer Cervus elaphus and wild boar Sus scrofa in the Netherlands. Acta Theriologica 45: $71-85$.

Güsewell S. 2003. Management of Phragmites australis in Swiss fen meadows by mowing in early summer. Wetlands Ecol. Manage. 11: 433 - 445.

Güsewell S. and Edwards P. 1999. Shading by Phragmites australis: a threat for species-rich fen meadows? Appl. Veg. Sci. 2: 61 - 70.

Güsewell S. and Le Nédic C. 2004. Effects of winter mowing on vegetation succession in a lakeshore fen. Appl. Veg. Sci. 7: 41 - 48.

Hájek M., Horsák M., Hájková P. and Díte D. 2006. Habitat diversity of central European fens in relation to environmental gradients and an effort to standardise fen terminology in ecological studies. Persp. Plant Ecol. Evol. Syst. 8: 97 - 114.

Haynes R.J. and Williams P.H. 1999. Influence of stock camping behaviour on the soil microbiological and biochemical properties of grazed pastoral soils. Biol. Fertil. Soils 28: $253-258$.

Humphrey J.W. and Patterson G.S. 2000. Effects of late summer grazing on the diversity of riparian pasture vegetation in an upland conifer forest. J. Appl. Ecol. 37: 986 - 996.

Jewell P.L., Güsewell S., Berry N.R., Käuferle D., Kreuzer M. and Edwards P.J. 2005. Vegetation patterns maintained by cattle grazing on a degraded mountain pasture. Bot. Helv. 115: $109-124$

Jones D.I.H. and Hayward M.V. 1975. Effect of pepsin pre-treatment of herbage on prediction of dry-matter digestibility from solubility in fungal cellulase solutions. J. Sci. Fd Agric. 26: $711-718$.

Lamoot I., Meert C. and Hoffmann M. 2005. Habitat use of ponies and cattle foraging together in a coastal dune area. Biol. Conserv. 122: $523-536$. 
Matejková I., van Diggelen R. and Prach K. 2003. An attempt to restore a central European species-rich mountain grassland through grazing. Appl. Veg. Sci. 6: $161-168$.

McGechan M.B. 2003. Modelling phosphorus leaching to watercourses from extended autumn grazing by cattle. Grass Forage Sci. 58: 151 - 159 .

McGechan M.B. and Topp C.F.E. 2004. Modelling environmental impacts of deposition of excreted nitrogen by grazing dairy cows. Agric. Ecosyst. Environ. 103: 149 - 164.

Menard C., Duncan P., Fleurance G., Georges J.-Y. and Lila M. 2002. Comparative foraging and nutrition of horses and cattle in European wetlands. J. Appl. Ecol. 39: 120 - 133.

Middleton B. and van Diggelen R. 2006. Effects of grazing, cutting and burning on fens. Appl. Veg. Sci. 9: $307-316$.

Mouissie A.M., Vos P., Verhagen H.M.C. and Bakker J.P. 2005. Endozoochory by free-ranging, large herbivores: ecological correlates and perspectives for restoration. Basic. Appl. Ecol. 6: 547 - 558.

Ohlson M. and Staaland H. 2001. Mineral diversity in wild plants: benefits and bane for moose. Oikos 94: $442-454$

Rozé F. 1993. Successions végétales après pâturage extensif par des chevaux dans une roselière. Bulletin d'Ecologie 24: $203-209$.

Schär C., Vidale P.L., Lüthi D., Frei C., Häberli C., Liniger M.A. and Appenzeller C. 2004. The role of increasing temperature variability in European summer heatwaves. Nature 427: $332-336$.

Stammel B., Kiehl K. and Pfadenhauer J. 2003. Alternative management on fens: response of vegetation to grazing or mowing. Appl. Veg. Sci. 6: $245-254$.

van den Bos J. and Bakker J.P. 1990. The development of vegetation patterns by cattle grazing at low stocking density in the Netherlands. Biol. Conserv. 51: $263-272$.

van Oene H., van Deursen E.J.M. and Berendse F. 1999. Plant-herbivore interaction and its consequences for succession in wetland ecosystems: a modelling approach. Ecosyst. 2: $122-138$.

Vinther E. 1983. Invasion of Alnus glutinosa (L.) Gaertn. in a former grazed meadow in relation to different grazing intensities. Biol. Conserv. 25: $75-89$.

WallisDeVries M.F. 1996. Nutritional limitations of free-ranging cattle: the importance of habitat quality. J. Appl. Ecol. 33: 688 - 702.

WallisDeVries M.F. and Schippers P. 1994. Foraging in a landscape mosaic: selection for energy and minerals in free-ranging cattle. Oecologia 100: $107-117$.

Warnke-Grüttner R. 1990. Okologische Untersuchungen zum Nährstoff- und Wasserhaushalt in Niedermooren des westlichen Bodenseegebiets. Diss. Bot. 148: 1 - 214.

Wilson J.B. and Agnew A.D.Q. 1992. Positive-feedback switches in plant communities. Adv. Ecol. Res. 23: 263 - 336. 